\title{
Prognostication of the Vector of Employee's Talent Development by Means of Cover Letter
}

\author{
Zoya V. Yakimova \\ Vladivostok State University Economics and Service \\ Email:yakimovazoya@yandex.ru
}

\section{Doi:10.5901/mjss.2015.v6n3s2p323}

\begin{abstract}
The basic source of competitiveness of any modern organization is the effective key and talented workers management. Talent management is a separate aspect of personnel management. However, researchers differ in the understanding of the concept of "talent management". At the same time, many authors (M. Batteris and B. Reuter, 2015; A. Robertson and G. Abbey, 2004; M. Effon, M. Ohrt, 2014; and others.) are unanimous in their opinion that such employees are distinguished by their ability in achieving unusually high results, the desire for continuous improvement and perfection, intrinsic motivation and enthusiasm. Such employees are successful, regardless of the post they occupy and regardless of the company they work in. The article exposes the etymology of the concept of "talent", a description of abilities gradation, the essence of the concept of "talent management" is revealed from the perspective of two approaches: psychological and managerial . A survey of the views of HRmanagers of several Russian companies on how to identify, develop and retain talented employees in the organization is conducted. The technology of personnel reserve formation as a variety of talent management programs is examined. The conducted research allows one to consider motivation letters of candidates for participation in the project "Personnel reserve" as a diagnostic tool of predicting the advisability of investing in the development of these employees.
\end{abstract}

Keywords: talent, man of talent, talent management, key employees, personnel reserve, cover letter;

\section{Introduction}

Outwardly, the talented employee is no different from any other ordinary one, his talent is manifested only in the course of professional activities and evaluated for results. Accordingly, any organization is in a certain area of risk when deciding whether to invest in potentially talented employees which haven't revealed their abilities yet. In this case, any employer always weighs the costs and prospects of the two alternative strategies of its talent pool replenishment.

The first strategy involves "headhunting" technology - enticing away ready-made key employees distinguished themselves from competitors. This strategy gives a quick guaranteed results, but is associated with high financial costs and the risk of leaving the "stars" at the suggestion of a more favorable option from competitors or from a mismatch of expectations with the actual conditions.

The second strategy is focused on "nurturing" talents in the context of one's own organization, which makes these employees more loyal and devoted by way of gratuity because of provided opportunities in self-development and selfactualization. But in this case the company is not immune to the "Netherbloom" effect when the investments have been made, the time spent, but there is no result - talent hasn't opened, or the results achieved do not meet investor expectations and goals of the organization.

The most advanced, in respect of management, organizations combine the two technologies to form the talent pool and attract already held "stars" for mentoring. However, in this case, the company may choose one of the approaches to the talent development.

The conducted analyze of talent management allowed to distinguished two main approaches: psychological and managerial.

The psychological approach is based on the human self-development intrinsic motivation. The organization in this case acts as a platform for man of talent self-actualization; it develops in accordance with its natural inclinations and abilities. The result defies planning, unpredictable and uncontrollable, but mutually beneficial for the organization and for the talent, representing a certain form of organizational symbiosis. By self-actualization the man of talent creates his masterpieces, using resources of the organization, and the organization profit, getting patents and copyrights to the results of man of talent self-expression.

Managerial approach is based on extrinsic motivation and man of talent labor activity results encouraging on the 
part of the organization. In this case, the organization initially sets the parameters of the expected result, selects the most capable and talented employees and encourages their professional activity through rewards for concrete results achieved.

Thus, if in the initial employee potential diagnostic one sets the parameter of motivation determination vector, it is possible to predict the way the talent will develop that will allow to shape and implement the most optimal and economically feasible program of talent support and development in the organization.

In the context of the present article a cover letter is suggested as such a diagnostic tool.

\section{Literature Review}

Talent Management is quite a new trend, singled out as one of the aspects of personnel management. Presumably, the term "talent management" was introduced by D. Watkins (Watkins, 1998) in one of his articles published (D.L. Watkins, 1998). But the understanding of the relationship between the degree of employee engagement in the innovation process, the development of staff capacity and efficiency of the organization had been recognized already in the 70s of XX-th century and had reached its peak of popularity in the 1990s. The leaders of many large organizations, such as, for example, Procter \& Gamble, General Electric, Microsoft, Cisco and others seriously thought about the question of identifying, developing and retaining talented employees in companies.

Pluralism of opinions and interpretations about the concept of "talent management" makes us turn to the original etymology of the term "talent" to clarify the differences between talent, endowment and genius.

\subsection{The etymology of the term "talent"}

Originally, the definition of "talent" stands for the denotation of weight and monetary unit used in a number of regions of Asia Minor: Ancient Greece, Egypt, Babylon, Persia. Figurative sense of talent understanding as a "gift of God" came from the New Testament through the parable of the three slaves. God gave five talents to the first slave, two talents to the second one and one talent to the last one, each talent according to slaves' abilities. The slave received five talents went and used them and made other five talents; the slave received two talents received other two; and the last one went and digged its talent in the earth. Thus, each of them has handled with his talent in his own way: the first one multiplied it (i.e., he was able to use his talent, develop it and achieve significant results), the second one exchanged it (i.e. he hasn't achieved great results, dispersing his efforts on minor, insignificant aspects), the third one buried it in the ground (i.e., lost) (The parable of talents, http://www.bible-center.ru/ru/bibletext/synnew_ru/mt/25:14-30).

Thus, one can conclude that the talent is an equivalent to a certain gift having a degree of graduation (it can be exchanged or multiply), as well as it can be controlled by one or another scenario: an effective way - to multiply, ineffective way - to change, dead-end way - to bury, lose.

\subsection{The role of natural and social aspects in talent development and levels of abilities gradation}

Confrontation between biological and sociological concepts (K.M. Gurevich, 2002), makes us think about the role of genetic predisposition (a gift of God, natural inclinations, heredity) and the influence of social and cultural environment factors (education, social environment, willpower) on the formation and development of talent intensity (expressiveness) degree (5).

So, in particular, the article of L.I. Kirsanova and O.A. Korotina (L.I. Kirsanova and O.A. Korotina, DOI: 10.5829/idosi.wasj.2014.31.05.14337, 2014) highlights the problematics of an individual who often cannot overcome or minimize the adverse effects of unsuccessful socialization, which is caused by, for example, a birth in rural area or village in which there is no a decent level of education and there is an atmosphere of stagnation and neglect (L.I. Kirsanova and O.A. Korotina, DOI: 10.5829/idosi.wasj.2014.31.05.14337, 2014). But it is impossible to ignore cases where a person has reached significant results without initial favorable social and cultural environment (for example, M.V. Lomonosov). Accordingly, the development of talent and self-improvement may be the product of the will and human freedom in protest against unfavorable conditions of the social environment.

Since the publication of the book "Genius and Heredity" (F. Galton, 1869), the problem of development and differentiation of talent is becoming increasingly important. Throughout the twentieth century, numerous studies were conducted. That contributed to the accumulation of knowledge about the nature of talent, predisposition to a particular activity, the development of abilities.

Direct participation in the abilities investigation was taken by B.M. Teplov (B.M. Teplov, 2002). In his view, the 
notion of "ability" integrates at least three features.

First, it is the individual psychological characteristics that distinguish one person from another.

Secondly, not all abilities are called general individual characteristics, but only those that are relevant to the successful fulfillment of any activity.

Thirdly, these individual features cannot be reduced to possessed skills, abilities or knowledge, but can explain the ease and speed of acquisition of these skills and knowledge (B.M. Teplov, 2002).

Later on a hierarchy of skills depending on the degree of their development was formulated. According to this hierarchy, the initial degree of development of abilities are natural inclinations as inborn structural features of the body and nervous system, causing a predisposition to the formation and development of abilities. They are followed by inclinations manifested in human desire to be engaged in certain activities. The combination of various advanced capabilities that lead to particularly successful activity in a particular area or multiple areas indicates the presence of talent. The highest level of talent is genius as the ability to create something completely new and meaningful to the culture as a whole and this of that sphere of activity in particular.

Thus, we come to the conclusion that talent as one of the levels of abilities manifestation is caused both by biogenetic factors (natural inclinations) and sociogenetic factors (affecting the formation of inclinations).

\subsection{The specificity of the concept of "talented employee"}

Understanding the results of extensive research conducted by McKinsey \& Company in order to find out how the attitude to the staff determines the success of the company represented in the book "War for Men of Talent" (E. Michaels, $\mathrm{H}$. Handfield-Jones, E. Axelrod, 2012) became the basis for the formation of modern concepts of talent management (Michaels, E. and other, 2012.).

In the present article our interest is associated with rather narrow aspect of talent research - namely, we are interested in the concept of talented employee of an organization. Despite the difference in terminology (in different literary sources such terms as "particularly valuable employees", "key employees", "talented people", "high potential employees» ( $\mathrm{HiPO}$ ), etc. may be used) in the field of contemporary personnel management all researches (M.Batteris, B.Reuter, 2005; A. Robertson, G. Abbey, 2004; M. Effon, M. Ohrt, 2014) concur that such employees are distinguished by their ability in unusually high results achieving, continuous improvement and perfection aspirating. Such employees possess intrinsic motivation and enthusiasm, intelligence and are able not only to offer an innovative idea but also to implement it. They are successful, regardless of the post they occupy and regardless the company they work in. Customary as a rule, these most valuable employees are personally responsible for greatest profit obtaining, new types of goods or services creating, reputation and image of the organization improving, good relations with business - partners and customers developing (M. Batteris and Reuter B., 2005; A. Robertson and G. Abbey, 2004; and M. Effron and M. Orth, 2014).

A group of researchers (E.M. Emelyanov and S. Povarnitsyna, 1998) offers an interesting approach, describing the specifics of talented employees manifestation at every stage of the life cycle of the company. Thus, for example, in the infancy of the company self-sufficient leader who is able to define the purpose and objectives, organize team will be regarded as a talented one. At the stage of rapid growth of the company especially valuable are highly qualified specialists, who achieve high results due to quickly adaptation to changes and ability to personal internal resources mobilization. In the context of the organization regulation, the category of talented employees includes those employees who in equal status show the best results and have a significant impact on the targets of the organization (E.N. Emelyanov and S.E. Povarnitsyna, 1998).

Such authors as A. Robertson and G. Abbey (A. Robertson and G. Abbey, 2004) published the results of their research in "Talent Management: How to benefit from the talents of your subordinates." are also not less significant. In this article potential conflicts between the expectations of employers and the expectations of the most talented employees are mentioned; the technology of promoting, supporting and inspiring talent are offered. Researchers had examined the particular characteristics of the term "talent" quite in detail. According to them, talented employees possess the following qualities: the desire for personal growth; the desire for constant forward moving; the desire to keep up everywhere; the desire for comprehension and results; the desire for action and choice; the desire for self-esteem; the pursuit of ease ( $N$. Osovitskaya, 2014).

M. Batteris and B. Reuter (M. Batteris and B. Reuter, 2005) consider the practical aspects of the most valuable employees management. The range of their research covers a range of topics from attracting and retaining talented employees to the role of the personnel manager in managing the "difficult" men of talent (M. Batteris and B. Reuter, 2005). 
Large quantity of works on talent management is made based on the experience of concrete organizations, for example, D. Mayer and J. Liker (D. Mayer and J. Liker, 2012), M. Imai (M. Imai, 2013) reflected the key concepts used in working with talented employees in TOYOTA company (M. Imai, 2013; J. Liker and D. Mayer, 2012; J. Liker, 2012).

Thus, analyzing the concept of different authors, we come to a conclusion that the talent in the context of the organization environment is the key, especially valuable employee, being of maximum benefit, being a source of competitive advantages of the organization, at the same time carrying a certain degree of money loss invested in his identification, development and retention.

\subsection{Psychological and managerial approaches to talent management}

Modern researchers in the field of HR-management believe (M.I. Litvinova, 2011) that the process of talent management is an attempt to predict which human resources will be required by a company, and create certain conditions for their timely recruitment, development and retention. Talent Management Technology is certain operations of a company, allowing using investment in talented personnel in middle and senior management (M.I. Litvinova, 2011).

More detailed definition is given by S.A. Kartashov (S.A. Kartashov, 2013) who understands talent management as a system of organizational, economic and socio-psychological measures aimed at increasing the level of competence in critical, from the standpoint of business, activities by introducing and developing programs for men of talent attraction, acquirement, development, promotion and retention (S.A. Kartashov, 2013).

Summarizing the results of studies (J. Budreau, 2014; S. Ivanova, 2014; and N. Osovitskaya, 2014), one can distinguish two major talent management strategies.

The first strategy is to find the best use of the natural talents of each employee.

The second strategy is to focus efforts on the search for men of talent with the potential for professional growth.

Proponents of the first strategy believe that every person is talented (has outstanding ability) in some way. The task of HR-employee is to identify these talents and make sure that the employee was able to show them to benefit the company. HR managers in implementing this particular strategy pick up two possible ways:

identify the talent of a new comer, i.e. not taking into account his specific post, conduct interviews, selecting the post for a person's talent;

- determine the talents of already working staff and move them to a better position for them, create optimal conditions for their development.

Proponents of the second strategy believe "talent" to be a potential for development, the capacity for effective mastering of information and new activities. Based on this principle, HR-specialists divide the entire staff of the company into a "key" staff, which is paid maximum attention by the company, and "other" staff. Usually the technology of personnel reserve forming is frequently used. Personal reserve is consists of potentially successful and talented staff with managerial or professional inclinations talent, selected for further "nurturing" and development.

Summing up, it is expected to introduce two approaches to talent management in accordance with defined strategies, namely, psychological and managerial approaches. The psychological approach corresponds with the strategy of finding the best use of natural talents of each employee. Managerial approach captures the essence of the strategy of selection of potentially talented employees and their talents development in accordance with the organization requirements.

The use of different aspects of talent management, personnel reserve forming, relationships with stakeholders building is a hot topic of research not only for profit-making organization but also for the public sector, including State University (E.A. Mogilevkin and A.S. Novgorodov, 2015; K.S. Solodukhin and A.A. Gresko, DOI: 10.5829/idosi.wasj. 2013.27.07.13690, 2013) which is reflected in the current research.

\section{Research Methodology}

\subsection{Participants}

The research was held in three stages:

At the first stage the participants of the research became the following: HR - managers, personnel management services specialists, heads of departments of Russian commercial organizations such as OJSC "MTS", OJSC "Rosbank", LLC "2GIS", LLC "Etiquette-DV", LLC "IMO", LLC "Primorsky Kombinat Reklamy ", LLC " Kelly Services C-I-S", SP Tregubova (Domotechnika), LLC " Biznes Klass", OJSC " Primsotsbank ", LLC "Zemchuzhina", LLC "Strannik", Hotel Hyundai, LLC "Avanta" , HC "Vladivostok", HC "Versailles", EA "Prospekts", LLC "TaymLizing", LLC "Ecker Konsulting", 
LLC "Pyat Zvezd", LLC "Ekvator", LLC "Renessans", HC Sunrise. In total in the survey 30 people, aged 26 to 48 years, including 18 women and 12 men were participating.

Simultaneously with the survey of representatives of business organizations there held a survey of heads of departments of the Federal State budget institution of higher education "Vladivostok State University of Economics and Service." In total 16 people, aged 30 to 54 years, including 12 women and 4 men took part in the survey.

The second stage of the research involved candidates for participation in the project "Personnel Reserve" held by Vladivostok State University of Economics and Service. In total the second stage of the research was attended by 80 people, aged 19 to 49 years, including 57 women and 23 men. Contingent was presented by students, teachers, researchers, representatives of the administrative and managerial staff.

In the third stage (exactly one year after) a second survey of a sample of participants of the second stage of the research was conducted. At this time, the research involved only 46 participants from the original sample of 80 people, which stands for $57.5 \%$.

\subsection{Instrument}

For the implementation of the first phase of the research, respondents were offered a questionnaire containing only 4 open questions:

- What differs men of talent from the rest of the staff?

- How to identify a talented employee?

- How to develop a talented employee?

- How to keep a talented employee in the organization?

For the second phase of the research the respondents claiming to participate in the project "Personnel Reserve" had been invited to draw up a cover letter, mandatory including three thematic blocks:

- Why do I pretend to participate in the project "Personnel reserve", what are my motives for participation;

- What kind of help and support do I need from the organization during the period of my participation in the project "Personnel Reserve";

- What useful can I offer for the organization in case of my participation in the project "Personnel Reserve".

Thus, during the second phase of the research the method of documents analysis was used. The Portfolio provided by the project participants was analyzed. The level of achievement of candidates at the "input" of the project "Personnel Reserve" was estimated. Alongside, individual development plans for a year provided by respondents and attested by project participants supervisors were analyzed.

Exactly one year later for the remaining project participants (57.5\%) there were surveyed held to collect feedback on the achieved results for the year, the dynamics of achievement and monitoring participants' opinions about the project as a whole.

The results of the survey and the cover letters were analyzed by applying the method of content analysis.

\section{Findings and Discussion}

\subsection{The results of the survey of employers' representatives (HR-managers, Personnel Management Service specialists, heads of departments)}

Analysis of the results of the survey of representatives of Russian organizations concerning submission of what talented employee differs from the ordinary employee, almost completely confirmed the results of opinions monitoring of foreign colleagues in HR - sphere.

It was found that talented employee can be described as a productive worker, consistently showing high results of work, as an expert in concrete field, who is able to quickly grasp the essence of the problem, make his own decisions and take responsibility for the results of that decision. There were also marked the ability and willingness to learn, selfdevelop, new information mastering. The most significant characteristic feature of a talented employee which set him apart is the ability to react quickly to changing situations and the ability to transform existing experience and knowledge to solve new, non-standard problems; the ability to work quickly and without errors. The most distinguishing feature of the talented worker which can tell him from the ordinary one, according to Russian employers, is enthusiasm for work and the ability to implement projects in life, get real results that far exceed the results of the average employee.

The question of how to identify a talented employee showed two different opinions:

$17.4 \%$ of respondents strongly believe that a man of talent, if he is a real one, will show itself without fail and there 
is no necessity for his talent further identification. The rest of the respondents offer a range of activities to identify a talented employee in the organization. Among them are the following:

- tracking up the best results for the performance of tasks, including tracking up dynamics (increase) indicators;

- judging self-organization (the way an employee can intelligently allocate his time and set priority in solving tasks);

- by way of communication (interviews, business communication, recommendations receiving);

- by way of inspections and testing (to charge a new project, to set a complex non-standard task, to conduct case-interview or assessment center);

- by way of opportunities for professional growth and development provision (training, organization of education and professional development);

- by way of competition (professional competitions organization, team or individual competitions with colleagues for the best result).

Some of the respondents (13.01\%) prefer a strategy of observation and analysis: employee initiative, the choice of professional tasks solving, the specifics of communications, etc.

It is worth while noting that many respondents (34.8\%) say that a talented employee outstands by his initiative, enthusiasm, a willingness to undertake new projects and unusual tasks. Such employees usually emit special vigorous activity energy, positive and intrinsic motivation, genuine interest in work performed and the results obtained.

The question of the possible ways of development of a talent did not cause controversy, but outlined four key vectors:

to reward (to reward for achievement, to award a prize, to promote);

to involve (to involve in corporate events, social and volunteer activities, organizational projects);

- to guide (to complicate the task, delegate some authority and responsibility, to form an individual program development);

not to hinder (to notice and encourage initiative showing, to provide freedom, independence and responsibility, to eliminate the problems associated with working conditions).

The question about talented employees in the organization relating revealed no unanimity among the respondents. The only aspect that the majority of respondents noted is a situational one- i.e. to each of the talented employees an individual approach should be selected. And then it all depends on the combination of specific factors of a given situation: someone will be retained due to career prospects opportunities, someone - due to decent working conditions and wages, and for someone favorable socio-psychological climate in the team will become paramount.

\subsection{The results of the analysis of cover letters of candidates to participate in the project "Personnel Reserve"}

In setting the task of writing a cover letter two conditions for respondents were made:

a cover letter must provide answers to three questions (why does one participate in the project, what kind of help / support does one expect from the organization, can one be useful for organizations during the period of one's participation in the project);

- the volume of a cover letter should not exceed 2 pages of printed text. technique.

The absence of other instructions and guidelines can allow considering a cover letter as a variation of projective

While analyzing cover letters nine types of letters were identified. They are described in Table 1 , and the ratio of the proportions of the distribution - in Figure 1 
Table 1. Types of cover letters

\begin{tabular}{|c|c|c|c|}
\hline № & Type of a cover letter & $\begin{array}{c}\text { Excerpts } \\
\text { frequency, \% }\end{array}$ & Description \\
\hline 1 & Cover letter - stamp/duplicate & 20,0 & $\begin{array}{l}\text { letters - duplicates - almost identical or very similar in form and content, } \\
\text { but with a slight variation of the letter. As a rule, provided by the } \\
\text { respondents, who are friends with each other, closely communicate and } \\
\text { submitted documents to the personnel reserve "to keep smb.'s company" }\end{array}$ \\
\hline 2 & $\begin{array}{l}\text { Cover letter - individual plan (focus } \\
\text { on the future) }\end{array}$ & 33,8 & $\begin{array}{l}\text { In his letter the candidate describes a very specific position, which plans } \\
\text { to take in the short term, indicates the certain improvement of } \\
\text { classification courses and concrete time the candidate wants them to } \\
\text { attend; what specific article (article title and journal) he plans to publish; } \\
\text { indicates even date of suggested events (year of article writing, } \\
\text { monographs publications, dissertations, etc.) }\end{array}$ \\
\hline 3 & Cover letter - gratitude & 5,0 & $\begin{array}{l}\text { In their letters the candidates recount their achievements through the } \\
\text { lenses of words of gratitude to the individuals, mentors, managers, whose } \\
\text { words, actions, assistance influenced the choice of ways and } \\
\text { prioritization. }\end{array}$ \\
\hline 4 & $\begin{array}{l}\text { Cover letter - achievement } \\
\text { (retrospection) }\end{array}$ & 13,8 & $\begin{array}{l}\text { In a letter the candidates set forth in detail their achievements as of today, } \\
\text { up to a list of all received certificates and the competitions won. }\end{array}$ \\
\hline 5 & Cover letter - life journey judgment & 8,8 & $\begin{array}{l}\text { The candidate justifies his goals for the future on the basis of life's journey } \\
\text { already traveled and the lessons learned. Concludes, realizing his } \\
\text { successes and failures, creates a positive attitude towards the future and } \\
\text { faith in himself, in his own strength, in his usefulness to society. }\end{array}$ \\
\hline 6 & Cover letter - prioritization & 3,8 & $\begin{array}{l}\text { In his letter the candidate focuses on the opportunity to redesign his key } \\
\text { priorities, to escape from the routine of weekdays for some really } \\
\text { important projects, to participate in some fateful events. }\end{array}$ \\
\hline 7 & Cover letter - a mirror of ambitions & 2,5 & $\begin{array}{l}\text { The candidate himself is essentially a man worthy of praise, who reached } \\
\text { significant results, but he requires surface attributes to confirm his } \\
\text { achievements and feed his ambition. Dissertation, academic status, } \\
\text { participation in projects - it is important and significant precisely because } \\
\text { it reflects and confirms the status in the eyes of those around one the } \\
\text { relevance and reliability of the candidate. Attributes and artifacts feed his } \\
\text { self-esteem. }\end{array}$ \\
\hline 8 & $\begin{array}{l}\text { Cover letter - a letter for an } \\
\text { addressee }\end{array}$ & 8,8 & $\begin{array}{l}\text { The choice of an addressee is also interesting. Someone addresses his } \\
\text { letter to an HR committee, or rector, or experts, but most of all just write a } \\
\text { cover letter to a dear reader. }\end{array}$ \\
\hline 9 & Cover letter - for long service & 3,8 & $\begin{array}{l}\text { In the letter the life journey of the candidate within one organization from } \\
\text { student days to his current position is analyzed. Describes the gradual } \\
\text { increase in skills, knowledge and experience. Emphasizes how much has } \\
\text { already been done for the organization and what one plans to do more in } \\
\text { the short term. }\end{array}$ \\
\hline
\end{tabular}

For vizualization let's reflect the results received in the diagram (Figure 1)

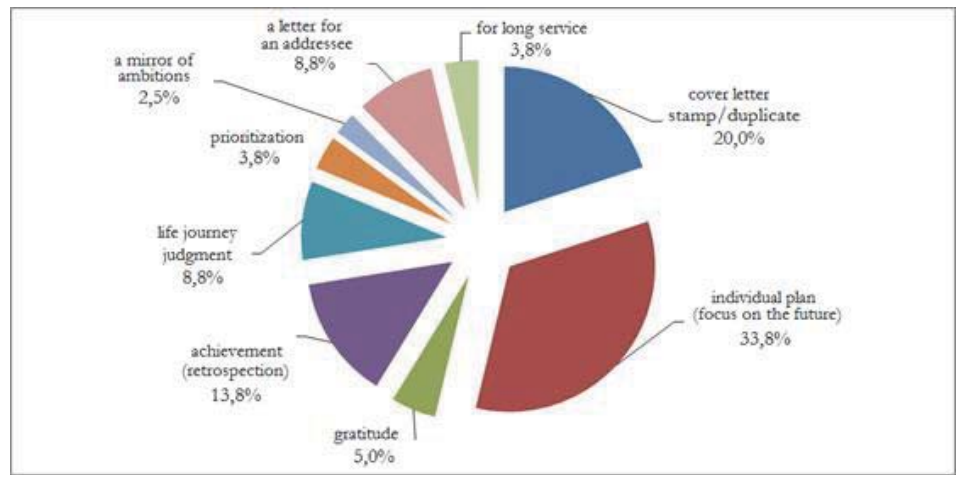

Figure 1. Proportions of distribution of types of cover letter in the excerpts 
A survey of participants of the project "Personnel Reserve" conducted exactly a year after has shown that the project was left by these people who have not reached virtually no results increase or did not get a reward for the slightest momentary achievement. Totally $57.5 \%$ of the original sample remained at the project, and the remaining $83.2 \%$ have showed real growth of results (salary levels increase, career development, position in the ranking improvement, etc.). In the project also remained those in whose lives there was no or radical changes for the better or for the worse during that year.

At the same time in the questionnaire feedback remaining reservists indicated the main (real) reasons for their participation, as reflected in Fig. 2

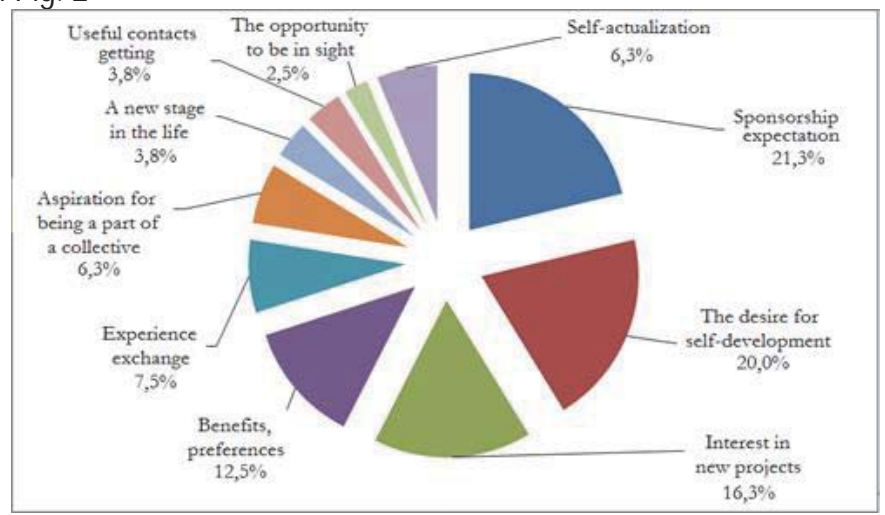

Figure 2. Real motives for the project "Personnel reserve" participation due to feedback results

When correlating cover letters of the respondents at the "input" of personnel reserve and the results of feedback at the "output" from the personnel reserve the following results were obtained:

- the project was left mainly by those candidates whose cover letters were classified according to the proposed classification into such categories as: cover letter - stamp / duplicate, a cover letter - gratitude, a cover letter a mirror of ambitions, a cover letter to the addressee. These candidates "digged" their talent because of getting no result.

- the candidates have remained in the project, but did not get the growth of result - the authors of cover letters, mostly related to the categories of a letter stamp / duplicate, a cover letter - for long service, a letter achievement (retrospection). These candidates "exchanged" talent - they haven't reached meaningful results the candidates who remained in the project and had progresses were those who were mainly the authors of such cover letters as: an individual plan (focus on the future), a cover letter - life journey judgment, a cover letter - prioritization. These candidates "increased greatly" their talent, having reached significant results.

Analysis of the real motives of participation in the project, received as "feedback" allows one to divide all motives into three categories:

- motives-remunerations (expectation of financial support, privileges and preferences);

- self-actualization motives (self-knowledge and self-development, a new stage in life, interest in new projects);

- communication motives (exchange of experience, aspiration for being a part of a collective, establishing new contacts, the opportunity to be in sight).

The ratio of these motives is shown in Figure 3.

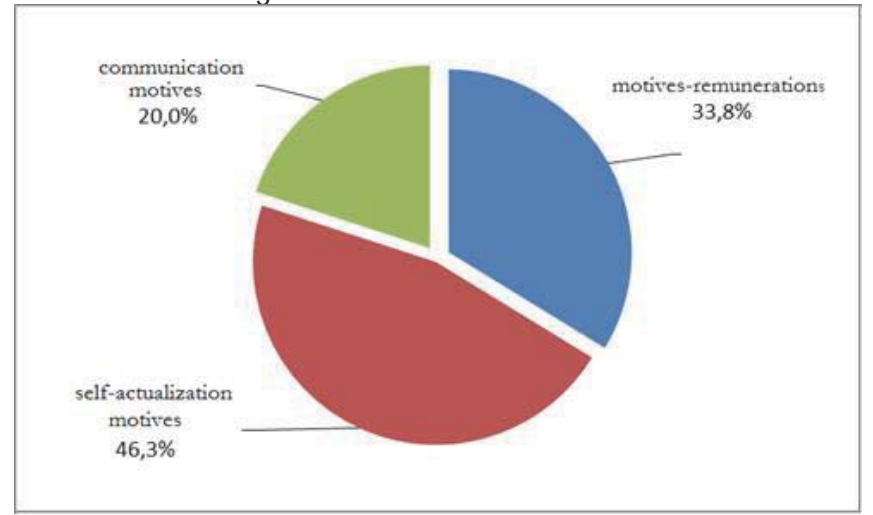

Figure 3. Generalization of the motives of participation in the project "Personnel reserve" by broad categories 
Thus, these results support our hypothesis of a psychological (based on self-development) and managerial (based on performing management through a reward) approaches to talent management. However, the research has provided additional results - the category of communication motives, being evidence of a talent not being able to develop itself in itself was indentified. A talented one has a need for interaction, communication, exchanging of experiences and ideas, being in sight and a part of a collective.

\section{Concluding Remarks}

The results got allow to draw the following conclusions:

1. Talented employees are the main source of competitiveness of the organization, but the talent is manifested only in the activities and evaluated for results.

2. The talent as a set of individual characteristics and one of the levels of abilities manifestation due to both biogenetic factors (natural inclinations) and sociogenetic factors (affecting the inclinations formation) and has a degree of manifestation (gradation). In addition, the talent can be controlled by one or another way of development: a dead-end variant - to bury; not an effective way - to change, an effective way - to multiply.

3. To improve the efficiency of an organization leaders use different technologies to replenish a pool of talent, including enticement (headhunting) and cultivation of their own talents (personnel reserve)

With the development of the company's staff two approaches can be applied: psychological and managerial. Psychological approach is based on the human intrinsic motivation for self-development. The organization provides conditions for the development of a man of talent in accordance with his natural inclinations and abilities, and further the organization benefits, receiving patents and copyrights to the results of a talented employee expression.

Managerial approach is based on extrinsic motivation and results of work encouraging on the part of the organization. In this case, the organization initially sets the parameters of the expected result, selects the most capable and talented employees and encourage their professional activity by way of rewards for concrete results achieved.

1. To minimize the risk of not returning the investment in staff development diagnostic tools are necessary. A cover letter can be regarded as such a tool. In the result of the research 9 categories of cover letters were identified (the letter "stamp / duplicate", "individual plan", "gratitude", "retrospection of achievements", "life journey judgments", "prioritization", "a mirror of ambitions", "a letter for an addressee"," for long service"). The authors of cover letter of the categories of "individual plan", "life journey judgment", "prioritization" have achieved the best results.

2. Analysis of the real motives of participation in the project of talent management "Personnel Reserve" allowed to group all motives in three key categories: motives-remunerations, self-actualization motives, communication motives. These results confirm the assumption of the possibility of the two approaches in the management of talent applying. The psychological approach is correspondent to self-actualization motives; the managerial approach is correspondent to motives-remunerations. The availability of a category of communicative motives indicates that a talent cannot develop on his own, that in addition to the need for self-development and the remuneration he has a strong need for interaction, communication, exchange of experiences and ideas, the desire to be in sight and to be a part of a collective.

\section{References}

Batteris, M., and Reuter B., 2005. Corporate diamonds: how to retain talented employees in the company. M.: GrossMedia. pp. 256. Budreau, J., 2014. Updated HR. Actual technology of using a talent in the business. M: Azbuka Biznesa. pp. 288.

Emelyanov, E.N. and Povarnitsyna, S.E., 1998. Business Psychology. M.: Armada pp. 511.

Effron, M., and Orth. M., 2014. Talent Management - a short course. M: Azbuka Biznesa, pp. 224.

Gurevich, K.M., 2002. The problem of social and biological in differential psychophysiology. Psychology of individual differences / ed. by Y.B. Gippenreytor, V.J. Romanov - M.: "CheRo", pp. 194-199.

Ivanova, S., 2014. Staff potential development: Professional competence, leadership, communication. M.: Alpina Publisher, pp. 279. Imai, M., 2013. Kaizen: The Key to Japan's Competitive Success. M.: Alpina Publisher, pp. 274.

Kartashov, S.A., 2013. Talent Management as HR-technology. Vestnik Omskogo Universiteta. Series "Economy". No. 1. pp. 85-94. Kirsanova, L.I., and Korotina O.A., 2014. On the Contents of the Protest Conscience in Russia. World Applied Sciences Journal, 31 (5), 930-934. DOI: 10.5829/idosi.wasj.2014.31.05.14337.

Liker, J. and Mayer D., 2012. Talented employees: Education and training of people in the dao TOYOTA. M.: Alpina Publisher, pp. 296. Liker J., 2012. Dao TOYOTA: 14 principles of management of the leading companies in the world. M.: Alpina Publisher, pp. 400. Litvinova, M.I., 2011. Talent Management: it is too early to make conclusions, there are more questions than answers. Current Issues in 
Economics and Management: materials of the international scientific conference (Moscow, April 2011). M.: RIOR, pp. 59-62.

Michaels, E., Handfild-Jones H. and Axelrod E., 2012. The war for talent. M.: Mann, Ivanov and Ferber, pp. 280.

Mogilevkin, E.A., and A.S. Novgorodov, 2015. Features of personnel reserve formation in the university in terms of higher education reforming in Russia. Higher education today. №1, pp. 40-45.

Osovitskaya, N., 2014. HR - Branding: talent management, online training, gamification and other 15 effective practices. SPb.: Piter, pp. 240.

Robertson, A., and Abbey G., 2004. Talent Management: How to benefit from the talents of your subordinates. Dnepropetrovsk: Balansklub, pp.200.

Solodukhin, K.S., Gresko, A.A., 2013. Using expected utility criterion for choosing strategies of interaction of university with stakeholders. World Applied Sciences Journal, 27 (7): 840-844. DOI: 10.5829/idosi.wasj.2013.27.07.13690.

The parable of talents. The Gospel of Matthew, Chapter 25, verses, pp. 14-30. http://www.bible-center.ru/ru/bibletext/synnew_ $\mathrm{ru} / \mathrm{mt} / 25: 14-30$

Teplov, B.M., 2002. Ability and endowments. Psychology of individual differences / ed. by Y.B. Gippenreytor, V.J. Romanov - M.: "CheRo", pp. 262-272.

Watkins, D.L., 1998. An Application Framework for Talent Management That Acts as a Central Feedback Center for all Organizational Functions / Softscape, Incorporated. 